Marquette University

e-Publications@Marquette

$11-1-2009$

\title{
Locating Decision Rights: Evidence from the Mutual Fund Industry
}

George D. Cashman

Marquette University, george.cashman@marquette.edu

Daniel N. Deli

DePaul University

Accepted version. Journal of Financial Markets, Vol. 12, No. 4 (November 2009): 645-671. DOI, (C) 2009 Elsevier B.V. Used with permission.

George D. Cashman was affiliated with Texas Tech University at the time of publication. 
Marquette University

\section{e-Publications@Marquette}

\section{Finance Faculty Research and Publications/College of Business Administration}

This paper is NOT THE PUBLISHED VERSION; but the author's final, peer-reviewed manuscript. The published version may be accessed by following the link in the citation below.

Journal of Financial Markets, Vol. 12, No. 4 (2009): 645-671. DOI. This article is (C) Elsevier and permission has been granted for this version to appear in e-Publications@Marquette. Elsevier does not grant permission for this article to be further copied/distributed or hosted elsewhere without the express permission from Elsevier.

\section{Locating Decision Rights: Evidence from the Mutual Fund Industry}

George D. Cashman

Department of Finance, Rawls College of Business, Texas Tech University, Lubbock, TX

Daniel N. Deli

Department of Finance, Kellstadt Graduate School of Business, DePaul University, Chicago, IL

\section{Abstract}

Mutual fund advisors make portfolio decisions for their funds on a daily basis. We examine the location of these portfolio decision rights on two dimensions. First, we consider the geographic location of the decision rights. Second, we consider whether the decision rights remain with an advisor or are allocated to an independent sub-advisor. We argue that the allocation of portfolio decision rights involves a tradeoff between the opportunity cost of not matching decision rights with specific knowledge, and the agency costs associated with moving the decision rights to the specific knowledge. The patterns in the location of decision rights are consistent with the tradeoff being a meaningful determinant of the allocation of decision rights in the mutual fund industry. We also find that funds 
that are predicted to be sub-advised and are sub-advised outperform those that are predicted to be sub-advised but are not.

\section{Introduction}

Baumol et al. (1990) note that the primary service mutual funds offer their investors is portfolio management. Portfolio management includes such activities as conducting research and making investment decisions. The location of these decision rights is important when value-relevant knowledge is unequally distributed across agents within the economy and this knowledge is costly to transfer among agents (i.e., it is "specific knowledge" as defined by Jensen and Meckling, 1992). Following the arguments of Fama and Jensen, 1983a, Fama and Jensen, 1983b and Jensen and Meckling (1992), we examine the role of specific information on the location of decision rights. First, we consider the geographic location of decision rights. Second, we consider whether decision rights remain with the advisor or are allocated to an independent third party, a sub-advisor. We argue that the allocation of portfolio decision rights on these two dimensions involves a tradeoff between the opportunity cost of not matching decision rights with specific knowledge, and the agency costs associated with moving decision rights to those with the specific knowledge.

We argue that when funds invest in foreign securities, the opportunity costs associated with not collocating decision rights with specific knowledge are relatively large. This leads us to predict that the likelihood that portfolio decision rights reside outside of the U.S. is greater for funds investing in foreign assets than funds investing in domestic assets. Consistent with our predication, we find that funds investing in foreign assets are more likely to allocate decision rights outside the U.S. than funds investing in domestic assets. The relation is large. In the univariate analysis, we find that foreign funds are seven times more likely to have decision rights located outside of the U.S. than domestic funds.

Beyond the simple foreign/domestic dichotomy, differences in business environments across countries offer another opportunity to test our arguments. Countries differ in their levels of openness/transparency and in their legal environments. We argue that in countries with less transparency and weaker legal environments, the opportunity cost of not shifting portfolio decision rights is large. Therefore, we expect that those funds investing in countries with less transparency and weaker legal environments to be more likely to have decision rights that reside outside the U.S. Our findings are consistent with that expectation.

We next examine the location of portfolio decision rights among funds investing in domestic assets. In particular, we examine the likelihood that portfolio decision rights are allocated to a sub-advisor as a function of the type of assets held by the fund. We predict that the allocation of decision rights to a sub-advisor is more likely when funds invest in assets that are harder to value. Our empirical results are consistent with that prediction. Specifically, in the univariate analysis, $16.38 \%$ of domestic equity funds outsource portfolio decision rights to an independent sub-advisor while the comparable number for debt funds is only $7.20 \%$.

We also conduct separate analysis on the allocation of portfolio decision rights to a sub-advisor within the sub-samples of domestic equity and domestic debt funds. Within equity funds, we argue that those funds investing for capital appreciation rather than income are more likely to suffer a greater opportunity cost from not matching portfolio decision rights with specific knowledge. This leads us to predict that funds investing for capital appreciation are more likely to allocate portfolio decision rights to sub-advisors than equity funds investing for income. We also predict that among debt funds, funds 
investing in corporate debt (as opposed to government debt) are more likely to allocate decision rights to a sub-advisor. Our results are consistent with these predictions.

Additionally, we argue that advisors may develop expertise with respect to generating knowledge that is specific to a given type of asset. We predict that the likelihood of portfolio decision rights being allocated to a sub-advisor is negatively related to the extent to which investment in that asset type constitutes a meaningful portion of an advisor's overall investments. For example, if an advisor specializes in valuing equities, they may still offer debt funds, but allocate portfolio decision rights for those funds to a sub-advisor. ${ }^{1}$ Consistent with this expectation, we find that advisors are less likely to outsource decision rights for funds pursuing an investment strategy in which the advisor specializes.

We also examine the effect that sub-advising has on fund performance. We find evidence that subadvised funds underperform their advisor-run counterparts. One concern with respect to this result, though, is that because sub-advised funds tend to invest in specific types of assets, it may just be the case that those types of assets did poorly over the sample period. To address this concern, we examine the returns to funds that are organized as predicted and funds that are not organized as predicted. We find that when the underlying economics suggest that funds should be sub-advised and they are, the funds perform better than funds that are predicted to be sub-advised, but are not. More generally, when we examine the deviation from our expected organizational form (advisor or sub-advisor managed), we see that the greater the deviation, the worse the fund performs. Additionally, we find that underperformance is worse for advisor run funds that we expect to be sub-advised, than for subadvised funds that we expect to be advisor run. This suggests that there are substantial opportunity costs associated with not collocating decision rights with relevant specific knowledge. Sub-advising, then, appears to be an economically useful organizational arrangement.

We make three important contributions to the literature. First, we provide empirical evidence on the cross-sectional variation of an organizational arrangement common to the mutual fund industry, which is largely absent from the literature. ${ }^{2}$ Documenting empirical regularities in organizational arrangements is important because it provides indirect evidence on what mutual funds do (or perhaps more accurately, their production functions). Fama and Jensen, 1983a, Fama and Jensen, 1983b argue that in a competitive environment the organizational arrangement that survives in supplying a demanded product will be the one that can supply the product at the lowest price while covering costs (Alchian, 1950). Our results suggest that mutual funds organize to collocate decision rights with knowledge in an efficient manor, and speak to the important role of specific knowledge in the mutual fund industry, while contributing to our understanding of the structure of the mutual fund industry.

Second, we contribute to a more general body of empirical research on contracting arrangements in the mutual fund industry. Recent examples include empirical examinations of mutual fund advisor contracts (Coles et al., 2000; Deli, 2002; Golec and Starks, 2004; Kuhnen, 2005; Warner and Wu, 2004) constraints on advisor discretion (Deli and Varma, 2002a, Deli and Varma, 2002b; Almazan et al., 2004), the structure of mutual fund fees (Chordia, 1996; Nanda et al., 2005), and the choice of organizational form (Deli and Varma, 2002a, Deli and Varma, 2002b). By adding to this growing body of research, our research furthers our understanding with respect to contracting, in general, within the mutual fund industry.

Finally, we contribute to the broad literature on the allocation of decision rights. If one is willing to assume a reasonably competitive equilibrium, then our results demonstrate the relevance of specific knowledge and the tradeoff between the opportunity cost associated with not matching decision rights 
with specific knowledge. This result contributes to a growing literature that examines the allocation of decision rights across a broad range of organizational contexts. ${ }^{3}$ We also extend the literature on the determinants of outsourcing. ${ }^{4}$ Unlike the traditional outsourcing literature that typically relies on asset specificity to explain outsourcing, our results suggest that the distribution of specific knowledge across economic agents is also relevant. ${ }^{5}$

A notable paper related to ours is Chen et al. (2007), which examines outsourcing in the mutual fund industry. Their paper differs from ours in several important ways. First, our predications with respect to sub-advising are based on a tradeoff between the costs and benefits associated with that organizational arrangement. That tradeoff is intimately linked to the types of assets held by the fund, as well as advisor characteristics. Chen et al. (2007) focus only on advisor characteristics as the determinants of outsourcing. Second, Chen et al. characterize any transference of decision rights as "outsourcing." Specifically while their sample includes the type of sub-advisory arrangements that we consider, they also include team managed funds (instances where funds split decision rights among multiple advisors) in their definition of outsourced funds. Consequently, $26 \%$ of their sample is "outsourced" whereas only $14 \%$ of our sample funds are sub-advised. We believe that the economics that drive the decision to split decision rights are likely to be different from those that drive the decision to shift decision rights. Blending team managed and sub-advised funds into a single "outsourced" classification (and in roughly equal proportion), potentially distorts the ability to draw meaningful inferences about either. The greatest difference in the papers, however, is in their conclusions. We conclude that economic efficiency linked to the types of assets managed drives meaningful patterns in sub-advising whereas Chen et al. (2007) find no such patterns in outsourcing. Also, these authors conclude that outsourced funds perform worse than funds that are not outsourced. We conclude that the effect of sub-advising on performance is dependent on the underlying economics, when the underlying economics suggest that a fund should be sub-advised, subadvised funds perform better than advisor run funds.

The rest of the paper proceeds as follows. In Section 2, we provide background on the role of fund advisors, as well as develop our hypotheses. Section 3 describes the sample and provides preliminary analysis. Section 4 reports results from the multivariate analysis examining the allocation of portfolio decision rights. In Section 5, we examine risk-adjusted returns as a function of sub-advising. Section 6 concludes.

\section{Background and hypothesis development}

\subsection{The role of fund advisors}

Tufano and Sevick (1997) describe a mutual fund as a legal entity with no employees to which investors allocate their portfolio decision rights. The fund, in turn, outsources all aspects of fund operation, including portfolio management, to an advisor. While it is true that the fund notionally "hires" the advisor, in practical terms it is the advisor who typically creates the fund in the first place. While the advisor typically maintains the portfolio decision rights, the advisor may choose to allocate portfolio decision rights to an independent third party (i.e., sub-advisor). Because we are examining funds sold and registered in the U.S., we take as our benchmark the situation where portfolio decision rights are located with a domestic advisor (without a sub-advisor). ${ }^{6}$ 


\subsection{Specific knowledge in the mutual fund industry}

Jensen and Meckling (1992) define specific knowledge as "knowledge that is costly to transfer among agents... ." Hayek (1945) emphasizes the central role of specific knowledge in organizational design. In particular,

... the economic problem of society is mainly one of rapid adaptation to changes in the particular circumstances of time and place, ... decisions must be left to the people who are familiar with these circumstances.

In essence, Hayek argues that there are gains associated with matching decision rights with specific knowledge (or, alternatively, there are opportunity costs associated with not matching decision rights with specific knowledge). In the context of mutual funds, specific knowledge is knowledge with respect to security value that is costly to transfer. If specific knowledge is unequally distributed in the economy, then the location of decision rights becomes relevant.

Jensen and Meckling (1992) note that there are two ways to match specific knowledge with decision rights. One is to transfer the specific knowledge to those with the decision rights. The other is to transfer the decision rights to those with the specific knowledge. They stress that transfer of specific knowledge is costly because it "... means effective transfer, not merely communication. The recipient of the knowledge is presumed to understand the message well enough to act on it." They argue further that the postponement of action due to knowledge transfer leads to costs from missed opportunities. We argue that the costs associated with knowledge transfer are likely to be large in the mutual fund industry, particularly in those instances where security pricing is most difficult (analytically intensive). We believe this to be the case because when security valuation is complex, it is more difficult to effectively transfer the relevant knowledge required to understand a value recommendation.

Because we link the cost associated with knowledge transfer to the complexity of asset pricing, we require some framework for characterizing that complexity. We contend that relative complexity stems from the relative difficulty of forecasting future cash flows and determining appropriate discount rates (i.e., risk premia). ${ }^{7}$ In those instances where future cash flows are difficult to forecast and appropriate discount rates are difficult to determine, we would characterize security pricing as relatively complex. In those instances where future cash flows are more easily predicted and appropriate discount rates are more easily determined, we characterize security pricing as less complex.

\subsection{Hypothesis development}

First, we develop hypotheses with respect to the allocation of decision rights. Second, we develop hypotheses with respect to the risk-adjusted returns produced by sub-advised funds.

\subsubsection{Hypotheses related to the location of decision rights}

Transferring decision rights to those with the relevant specific knowledge involves costs. There is an extensive literature documenting the agency costs associated with delegated decision rights (c.f., Jensen and Meckling, 1976). The location of decision rights is an exercise in trading off the costs of not matching decision rights with specific knowledge and the agency costs of shifting decision rights to those with the specific knowledge. In broad terms, we expect that when the opportunity costs of not matching decision rights with specific knowledge are large, we will observe decision rights being transferred to those with the relevant specific knowledge. On the other hand, when the opportunity costs are low, we do not expect to observe the transfer of decision rights. 
We first consider this tradeoff from a geographic perspective. We contend that there is greater specific knowledge in valuing foreign assets and that the specific knowledge associated with foreign assets is more likely to reside outside the U.S. ${ }^{8}$ For example, valuation of foreign assets requires not only an estimation of future cash flows and appropriate discount rates, but also an understanding of how valuation is affected by differences in the business, legal, and tax environments. We contend that the specific knowledge associated with foreign assets is more likely to reside outside of the U.S. This means that the opportunity costs of retaining portfolio decision rights within the U.S. are large. Therefore, we have the following hypothesis:

$\mathbf{H}_{1}$. Funds investing in foreign securities are more likely to locate portfolio decision rights outside of the U.S. than funds investing in domestic securities.

La Porta et al. (1997) as well as others have documented significant differences in the business environment across different countries, and that these differences can have an economic impact. When the business environment within the country that the fund invests in is such that it increases the value of country-specific knowledge, we expect the fund to be more likely to shift decision rights outside the U.S. ${ }^{9}$

$\mathbf{H}_{2}$. Among funds investing outside of the U.S., those funds investing in countries whose business environments suggest greater country-specific knowledge are more likely to shift decision rights outside of the U.S. than funds investing in countries where such knowledge is less valuable.

We next consider the tradeoff between the opportunity cost of not matching decision rights with specific knowledge and the agency costs associated with moving decision rights to an independent subadvisor for domestic funds. Because equity is a residual claim and generally involves greater risks than debt, we assume that equity pricing is more complex than debt pricing. ${ }^{10}$ Greater pricing complexity for equities implies greater difficulty in the effective transfer of knowledge. This, in turn, suggests the movement of decision rights to those with the relevant specific knowledge, which we capture empirically by examining the presence of a sub-advisor. We view the presence of a sub-advisor as being indicative of a situation where decision rights are transferred to those with the relevant knowledge leading to our third hypothesis.

$\mathbf{H}_{3}$. Funds investing in equity are more likely to allocate decision rights to a sub-advisor than funds investing in debt.

We next examine the location of decision rights within equity funds and debt funds. Among equity funds, we argue that pricing is more difficult for funds investing for capital appreciation than it is among funds investing for income. For example, capital appreciation funds tend to invest in firms with greater growth opportunities and smaller dividends, making future cash flows more difficult to predict. Among debt funds, we argue that pricing is more complex for funds investing in corporate debt than it is for funds investing in U.S. government debt-corporate debt potentially involves some amount of default risk making deriving the appropriate discount rate more difficult. ${ }^{11}$ This leads to our next two hypotheses.

$\mathbf{H}_{4}$. Among equity funds, funds investing for capital appreciation are more likely to allocate decision rights to a sub-advisor than funds investing for income.

$\mathbf{H}_{5}$. Among debt funds, funds investing in corporate debt are more likely to allocate decision rights to a sub-advisor than funds investing in government debt. 
It is possible that advisors specialize in producing information regarding certain types of assets. That same advisor, though, may find it valuable to offer a broad range of fund types; Gallaher et al. (2006) find that the more investment strategies a mutual fund family offers, the larger the flows to the family. Suppose an advisor specializes in producing information relevant to the pricing of equity. The advisor may retain portfolio decision rights with respect to equity portfolios, but outsource the running of its debt funds to a sub-advisor. This argument suggests the following hypothesis.

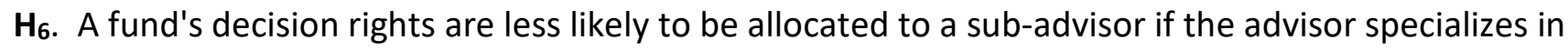
managing that type of fund.

\subsubsection{Hypothesis related to fund risk-adjusted returns}

Competitive equilibrium implies that sub-advised funds' risk-adjusted returns should be indistinguishable from non-sub-advised funds' risk-adjusted returns. If sub-advised funds produced systematically lower risk-adjusted returns, we would expect sub-advisors to be competed out of the marketplace. If, on the other hand, they produced systematically positive risk-adjusted returns, we would expect all funds to be sub-advised. That sub-advising exists and that not all funds are subadvised suggests the following hypothesis.

$\mathbf{H}_{7}$. Sub-advised funds produce risk-adjusted returns that are indistinguishable from the risk-adjusted returns produced by funds that are not sub-advised.

As noted, this hypothesis is based on the assumption that the mutual fund industry is competitive. Wahal and Wang (2008) find evidence that the mutual fund industry is a competitive marketplace. It may not be perfectly competitive, however. Warner and Wu (2004) point out that mutual funds are differentiated products with specific clienteles and that investors face both search and switching costs. It is conceivable, then, that sub-advised and advisor-run performance might deviate from one another (to a degree) without the worse performing of the two being competed out of the marketplace. We make use of this intuition in Section 5 to motivate comparing the performance of funds that are predicted to be sub-advised and are sub-advised to the performance of those funds that are predicted to be sub-advised but are run by their advisors.

\section{Sample and preliminary analysis}

\subsection{Sample}

Our data is from an investment company's N-SAR filings with the SEC. All regulated investment companies are required to file two N-SARs annually, one covering the first six months of the fiscal year (N-SARA) and the second covering the full year (N-SARB). ${ }^{12}$ We search the SEC's EDGAR website for all $\mathrm{N}$-SARB filings during the calendar year of 2002. Ideally, we would consider multiple years of observations. However, we limit our sample to one year of data because of limitations in our ability to collect advisor and sub-advisor ownership information that is critical to identifying instances of true shifting of decisions rights and not merely moving decision rights within an advisory organization. This limitation is discussed in detail below.

We examine funds' answers to various questions to determine the identity of the fund's advisor and sub-advisor (if it has one), whether a fund invests primarily in U.S. securities or foreign securities, whether a fund invests primarily in equity or debt, whether a fund invests in derivative securities, ${ }^{13}$ whether a fund invests in restricted securities, the amount of fund assets, and the level of fund turnover (the lesser of purchases or sales divided by average net asset value). For equity funds, we 
collect each fund's stated primary investment objective. We use the stated primary investment objective to classify whether the fund invests for capital appreciation or for income. ${ }^{14}$ For debt funds, we also collect the composition of each fund's portfolio.

We also use funds' answers to determine what countries the fund invests in. We calculate a measure of the transactions costs, openness/transparency, and two measures for the rule of law for each country. We use Lesmond et al. (1999) measure of transaction costs, which captures both direct and indirect trading costs. Higher values of this measure indicate greater trading costs. To measure openness/transparency, we follow Jin and Myers (2006) and use the disclosure measure from the Global Competitiveness Report. Higher values indicate more/better disclosure. Our first rule of law measure is the Corruption Perception Index published by Transparency International, averaged over 1993-2003, where higher values indicate less corruption. Our second rule of law measure is La Porta et al. (1999) measure of good governance, which is the sum of their Property Rights Index and their Business Regulation Index. Higher values of this measure indicate that private property is protected and regulations are less burdensome. When funds invest in multiple countries, we use the average of each measure (equally weighted across countries).

In addition to the N-SAR filings, we also retrieved each advisor's and sub-advisor's form ADV filing. Form ADV identifies various characteristics for firms supplying advisory services to a registered mutual fund. While we use form ADV to identify the country in which the advisor or sub-advisor is located, our principal use of the ADVs is to identify advisor and sub-advisor owners. It is not uncommon for a subadvisor to be owned by an advisor. For example, Jennison Associates, which is a sub-advisor to the Prudential Natural Resources Fund, is owned by Prudential Investment Management Inc., which also happens to be the fund's advisor. Also, there exist cases where an advisor and sub-advisor share a common owner. We do not consider these types of arrangements to be clear indications of the transfer of portfolio decision rights from one party to another. Consequently, when we examine the allocation of decision rights to a sub-advisor, we are actually examining the allocation of decision rights to an unaffiliated sub-advisor (where by unaffiliated we mean that the advisor does not own the subadvisor or the advisor and sub-advisor do not have a common owner). ${ }^{15}$ Unfortunately, the SEC does not maintain historical ADV filings, but rather, retains only the most recent revision on file. Thus, it is not possible to compile a panel of ADV filings from which to draw ownership data through time. Our ADV filings were collected in 2003.

Chen et al. (2007) use the same data source and a similar "snapshot" of ownership data, but they assume that ownership does not change over their entire sample period. Given their assumption, they construct a panel dataset. Conversations with an SEC employee suggest that approximately $5 \%$ of advisory firms experience changes in ownership in any given year and thus assuming stable ownership among advisory firms over long periods of time may be problematic. We are not willing to make such an assumption and so we do not construct a panel dataset. It should be noted, though, that both approaches offer benefits (and costs).

While both Chen et al. (2007) and ourselves use ADV filings to identify ownership, our classification processes differ in an important way. Chen et al. classify as "outsourced" any fund with at least one investment advisory firm that is not owned by, or shares a common third-party investor with the fund family. We identify as "sub-advised" any fund that allocates portfolio decision rights to an independent sub-advisor. We exclude funds with multiple advisors from the sample as these funds have split decision rights rather than transferred decision rights. We suspect that the economics that drive the economic expedience of splitting decision rights may be different than those driving the allocation of 
decision rights from an advisor to a sub-advisor, therefore we exclude team managed funds from the analysis. Using our methodology, we find that $13.6 \%$ of our sample is sub-advised, which is consistent with Baumol et al. (1990), who find that $12.7 \%$ of their sample of funds are sub-advised, as well as the testimony of Eliot Spitzer, who states that "fewer than $20 \%$ of all mutual funds employ sub-advisors." 16 Using their methodology Chen et al. (2007) find that 26\% of their sample is outsourced in 2002.

Notably, if we were to include team managed funds in our characterization of sub-advised funds, $27 \%$ of our funds would be classified as sub-advised.

To be included in the final sample, a fund must report each of the above data items on form N-SAR, as well as have a form ADV filing. Table 1 provides a description of the sample. In Panel A, we see that the final sample consists of 3,724 funds. Our sample funds invest primarily in equities ( $70.8 \%$ of funds). Equity funds are roughly split between those investing for capital appreciation and those investing for income $(1,203$ and 1,433, respectively). Within debt funds, government debt funds outnumber corporate debt funds (648-258). The overall sample is heavily weighted toward domestic funds$87.1 \%(3,245)$ of our sample funds are domestic funds and the remaining $12.9 \%(479)$ are foreign.

Table 1. Sample description.

Our data are from the SEC's Electronic Data Gathering and Retrieval (EDGAR) website. The source is investment company form N-SARB and advisor form ADV. We collect data for those funds that filed N-SARs during the calendar year 2002. We examine funds' answers to various questions on form N-SAR to determine whether a fund invests primarily in equity or debt. For equity funds we collect each fund's stated primary investment objective. For debt funds we collect the composition of each fund's portfolio. Debt funds are classified by what type of debt makes up the single largest percentage of portfolio assets. Number of funds managed and total assets managed are measured within-sample. Equity concentration is assets under management in equity funds divided by the total assets managed by an advisor (or sub-advisor). Percent located in foreign country is the percent of either advisors or sub-advisors that are located outside of the U.S.

Panel A: Sample composition

Fund type:

Number (\% of sample)

Full Sample

3,724

Equity

$2,636(70.8)$

Capital

appreciation

Income

Debt

Government

Corporate 258 (6.9)

Foreign

Domestic

$3,245(87.1)$

Panel B: Advisory firm characteristics. The number is each cell is the mean (median) across either all advisor firms or across all sub-advisor firms. Total assets managed are in $\$$ thousands. 


\begin{tabular}{|c|c|c|c|c|}
\hline & $\begin{array}{l}\text { Number of funds } \\
\text { managed }\end{array}$ & $\begin{array}{l}\text { Total assets } \\
\text { managed }\end{array}$ & $\begin{array}{l}\text { Equity } \\
\text { concentration }\end{array}$ & $\begin{array}{l}\text { Percent located in } \\
\text { foreign country (\%) }\end{array}$ \\
\hline \multirow[t]{2}{*}{ Advisor firms } & 7.2 & $4,432.9$ & $78.9 \%$ & 3.3 \\
\hline & (2) & $(200.0)$ & $(100 \%)$ & \\
\hline \multirow[t]{2}{*}{ Sub-advisor firms } & 4.8 & $1,528.8$ & $83.4 \%$ & 7.6 \\
\hline & $(2)$ & $(366.5)$ & $(100 \%)$ & \\
\hline
\end{tabular}

Panel B of Table 1 provides information on the advisors and sub-advisors in our sample. There are 549 unique fund advisors and 275 unique sub-advisors. Advisors manage more funds (7.2) than subadvisors (4.8), on average. The difference (not reported) is statistically significant ( $p$-value=.0008). We measure equity concentration as the amount of equity assets managed divided by total assets managed (within sample). In Panel B we see that sub-advisors tend to be more concentrated in equity assets than advisors. This result is consistent with the hypothesis that equity funds are more likely to be sub-advised than debt funds.

\subsection{Preliminary analysis}

For our full sample, 138 (4.2\%) funds locate decision rights outside of the U.S. In Panel A of Table 2 we see, however, that there is a meaningful difference in that percentage conditional on whether a fund invests in domestic or foreign assets. For funds investing in domestic assets, the portfolio decision rights reside outside the U.S. $2.1 \%$ of the time. For funds investing in foreign assets, however, $14.4 \%$ of the funds have decision rights that reside outside the U.S. Essentially, there is almost a seven-fold difference in the likelihood of portfolio decision rights residing outside the U.S. conditional on whether a fund is investing domestically or outside of the U.S. This result is consistent with our hypothesis that funds investing in foreign assets are more likely to have portfolio decision rights located outside of the U.S.

Table 2. Univariate analysis of the location of portfolio decision rights.

Our data are from the SEC's Electronic Data Gathering and Retrieval (EDGAR) website. The source is investment company form N-SARB and advisor form ADV. We collect data for those funds that filed N-SARs during the calendar year 2002. We examine funds' answers to various questions to determine fund type. For equity funds we collect each fund's stated primary investment objective. We classify those funds that state that their primary investment objective is either aggressive capital appreciation, capital appreciation, or growth as funds investing for capital appreciation. Funds investing for growth and income, income, or total return are classified as investing for income. For debt funds we collect the composition of each fund's portfolio. Debt funds are classified by what type of debt makes up the single largest percentage of portfolio assets.

Panel A: Proportion of funds with decision rights held by advisor or sub-advisor outside of the U.S. ( $N=3,724$ funds).

$$
\text { Domestic funds (\%) Foreign funds (\%) }
$$

Percent of funds with foreign 2.13

advisor or foreign sub-

advisor $\chi^{2}$ test for equality in proportions ( $p$-value)

14.41
176.3 (<.0001) 
Panel A: Proportion of funds with decision rights held by advisor or sub-advisor outside of the U.S. ( $N=3,724$ funds).

$$
\begin{array}{ll}
\text { Domestic funds (\%) Foreign funds (\%) } \quad \begin{array}{l}
\chi^{2} \text { test for equality in } \\
\text { proportions ( } p \text {-value) }
\end{array}
\end{array}
$$

Panel B: Proportion of funds with decision rights allocated to a sub-advisor by fund type $(N=3,245$ domestic funds).

$$
\text { Debt funds (\%) Equity funds (\%) }
$$

$\chi^{2}$ test for equality in proportions ( $p$-value)

$\%$ of funds with a sub-

$51.2(<.0001)$

advisor

Panel C: Proportion of equity funds with decision rights allocated to a sub-advisor by reported fund investment objective ( $N=2,204$ domestic equity funds).

$$
\begin{array}{lll}
\text { Funds investing for } & \text { Funds investing for } & \chi^{2} \text { test for equality in } \\
\text { income (\%) } & \text { capital appreciation (\%) } & \text { proportions ( } p \text {-value) }
\end{array}
$$

$\%$ of funds with a sub-

18.23

$2.2(.141)$

advisor

Panel D: Proportion of debt funds with decision rights allocated to a sub-advisor by debt fund type ( $N=1,041$ domestic debt funds).

$\begin{array}{llll} & \begin{array}{l}\text { Government debt } \\ \text { funds (\%) }\end{array} & \begin{array}{l}\text { Corporate debt funds } \\ (\%)\end{array} & \begin{array}{l}\chi^{2} \text { test for equality in } \\ \text { proportions ( } p \text {-value) }\end{array} \\ \begin{array}{l}\text { \% of funds with a sub- } \\ \text { advisor }\end{array} & 5.26 & 10.41 & 9.7(.002)\end{array}$

Panel B of Table 2 reports the proportion of debt and equity funds with sub-advisors. Overall, $13.4 \%$ of domestic funds allocate portfolio decision rights to a sub-advisor. We see in Panel B, however, that there are meaningful differences in the allocation of portfolio decision rights to a sub-advisor across debt and equity funds. Specifically, $7.2 \%$ of debt funds allocate portfolio decision rights to a subadvisor compared with $16.4 \%$ for equity funds. This is consistent with our third hypothesis that advisors are more likely to allocate portfolio decision rights to a sub-advisor for equity funds than for debt funds.

Within domestic debt funds there is also a meaningful difference in the likelihood that portfolio decision rights are allocated to a sub-advisor conditional on whether a fund invests in corporate debt or government debt. In Panel D of Table 1, for funds investing in government debt, portfolio decision rights reside with a sub-advisor $5.3 \%$ of the time. For funds investing in corporate debt, however, $10.4 \%$ of funds allocate decision rights to a sub-advisor. This is consistent with our fifth hypothesis that among debt funds, those investing in corporate debt are more likely to allocate portfolio decision rights to sub-advisors than funds investing in government debt.

Our preliminary analysis yields results that are broadly consistent with our hypotheses regarding the location of decision rights. Specifically, funds investing in foreign assets are more likely to have portfolio decision rights allocated outside the U.S. Among domestic funds, those investing in equities are more likely to have portfolio decision rights allocated to a sub-advisor. Also, among debt funds, those funds investing in corporate debt are more likely to have decision rights allocated to a sub- 
advisor than debt funds investing in government debt. These results are different from those of Chen et al. (2007), who find "roughly the same degree of outsourcing across styles." Of course, simple univariate comparisons implicitly hold other factors that potentially affect the location of portfolio decision rights constant, for example, advisor characteristics. To address that potential limitation, we examine the location of decision rights in a multivariate setting.

\section{Multivariate analysis of the location of decision rights}

In this section, we first consider the geographic location of portfolio decision rights. We then consider the allocation of decision rights to sub-advisors. We use a LOGIT model in all our analyses to test our hypotheses in a multivariate setting. The coefficients we report represent the change in the probability associated with an indicator variable taking a value of one (versus zero), or in the case of a continuous explanatory variable, the change in the probability associated with a two-standard-deviation increase in the variable (relative to the probability implied by evaluating the function with all dichotomous variables set equal to zero and all continuous variables evaluated at their means).

\subsection{Locating decision rights outside of the U.S.}

In Table 3 we examine the geographic location of decision rights. Our first hypothesis is that funds investing in foreign assets are more likely to have portfolio decision rights residing outside of the U.S. It is important to remember that this test examines the location of decision rights from a geographic perspective. It could be argued that there is little reason to expect, ex ante, any difference in the likelihood that equity funds are more or less likely than debt funds to have decision rights residing outside the U.S. Nevertheless, we include an equity variable in the LOGIT analysis to control for potential differences between the two. It could also be argued that among foreign funds, foreign equities entail more specific knowledge than foreign debt. This argument suggests the interaction of the foreign and equity variables. We include that interaction term in the second regression of Table 3. We also control for fund size (natural log) and portfolio turnover as well.

Table 3. Logit analysis of the geographic location of portfolio decision rights.

Our data are from the SEC's Electronic Data Gathering and Retrieval (EDGAR) website. The source is investment company form N-SARB and advisor form ADV. We regress an indicator variable capturing whether portfolio decision rights are held outside of the U.S. on the various fund characteristics. Foreign is a dichotomous variable taking a value of one if a fund invests primarily in foreign securities and zero if invests primarily in domestic securities. Equity is a dichotomous variable taking a value of one if a fund invests primarily in equity securities and zero if invests primarily in debt securities. Foreign*Equity is the product of Foreign and Equity. Ln(Fund Size) is the natural log of fund assets. Turnover is the lesser of purchases or sales divided by average net assets. In the case of a dichotomous explanatory variable, the coefficient we report represents the incremental effect of that variable taking the value of one relative to the probability captured by the intercept. In the case of a continuous explanatory variable, the coefficient is the change in the probability implied by a two-standard-deviation increase in the variable (relative to the probability implied by evaluating the function with all dichotomous variables set to zero and all continuous variables evaluated at their means). For example, in the first regression a foreign fund is $10.4 \%$ more likely to have decision rights located outside of the U.S. than a domestic fund. pseudo- $R^{2}$ is calculated as $1-[\ln L(\Omega) / \ln L(\omega)]$ where $L(\omega)$ is the likelihood function under the null hypothesis that all coefficients are 0 and $L(\Omega)$ is the likelihood function evaluated using the estimated coefficients. ${ }^{* *}$ indicates significance at the $1 \%$ level. * indicates significance at the $5 \%$ level. 
(1)

$\begin{array}{lll}\text { Intercept } & 0.017^{* *} & 0.017^{* *} \\ & (69.17) & (67.66) \\ \text { Foreign } & 0.104^{* *} & 0.113^{* *} \\ & (121.36) & (18.75) \\ \text { Equity } & 0.005 & 0.0055 \\ & (1.16) & (1.09) \\ \text { Foreign*Equity } & & -0.002 \\ & & (0.05) \\ \text { Ln(Fund Size) } & 0.009^{*} & 0.0084^{*} \\ & (5.14) & (5.17) \\ \text { Turnover } & -0.0002 & -0.0003 \\ & (0.003) & (0.006) \\ \text { pseudo- } R^{2} & 0.033 & 0.033 \\ \text { Obs. } & 3,724 & 3,724\end{array}$

The results reported in Table 3, like those of the univariate analysis, are consistent with our first hypothesis. Foreign funds are more likely to locate portfolio decision rights outside the U.S., than funds investing in domestic securities. In the first regression of Table 3, funds investing in foreign assets have a ten percentage point greater likelihood of having portfolio decision rights located outside the U.S. than a fund investing in domestic assets $(12.1 \%$ vs. $1.7 \%)$. Finally, the insignificant coefficient on the equity indicator and the interaction term suggests that it is the foreign nature of the assets rather than their type that is important in determining the geographic location of the decision rights.

Next, we examine how variation in foreign business environments affects the geographic location of decision rights. Our second hypothesis is that among foreign funds, those investing where local specific knowledge is more valuable will be more likely to have decision rights outside of the U.S. Our expectation is that the likelihood of shifting decision rights outside of the U.S. will be positively related to transaction costs, negatively related to our measure of disclosure, and negatively related to the ruleof-law.

Table 4 provides evidence consistent with our second hypothesis. We see that as country trading costs increase, decision rights are more likely to be held outside of the U.S. Model 1 shows that a two standard deviation increase in trading costs above the mean increases the likelihood of exporting decision rights by 17 percentage points ( $27 \%$ compared to $10 \%$ ). Additionally, Models $2-5$ show us that as foreign business environments get worse and the value of country-specific knowledge increases, funds are more likely to export decision rights. In general, as the amount of transparency and the rule of law decrease, funds are more likely to have decision rights outside of the U.S.

Table 4. Logit analysis of the geographic location of portfolio decision rights.

Our data are from the SEC's Electronic Data Gathering and Retrieval (EDGAR) website. The source is investment company form N-SARB and advisor form ADV. We regress an indicator variable capturing whether portfolio 
decision rights are held outside of the U.S. on the various fund characteristics. Equity is a dichotomous variable taking a value of one if a fund invests primarily in equity securities and zero if invests primarily in debt securities. Ln(Fund Size) is the natural log of fund assets. Turnover is the lesser of purchases or sales divided by average net assets. Countries is the number of countries where the fund has a custodian. Trading Costs is the mean of the Lesmond et al. (1999) measure of country trading costs. Disclosure is the mean of the Jin and Myers (2006), measure of the country disclosure. Corruption is the mean of the average Corruption Perception Index over 1993-2003. The value of Corruption increases with lower levels of corruption. Goodgov is the sum of the Property Rights Index and the Business Regulation Index. In the case of a dichotomous explanatory variable, the coefficient we report represents the incremental effect of that variable taking the value of one relative to the probability captured by the intercept. In the case of a continuous explanatory variable, the coefficient is the change in the probability implied by a two-standard-deviation increase in the variable (relative to the probability implied by evaluating the function with all dichotomous variables set to zero and all continuous variables evaluated at their means). For example, in the first regression an equity fund is $1.8 \%$ more likely to have decision rights located outside of the U.S. than a debt fund. pseudo- $R^{2}$ is calculated as $1-[\ln L(\Omega) / \ln L(\omega)]$ where $L(\omega)$ is the likelihood function under the null hypothesis that all coefficients are 0 and $L(\Omega)$ is the likelihood function evaluated using the estimated coefficients. ${ }^{* *}$ indicates significance at the $1 \%$ level. ${ }^{*}$ indicates significance at the $5 \%$ level.

(1) (2) (3)

Intercept

Equity
Ln(Fund Size)

Turnover

Countries

Trading Costs

Disclosure

Corruption

Goodgov

pseudo- $R^{2}$

Obs.

$0.102^{* *}$

(22.47)

0.041

0.032

0.032

(1.58)

$-0.028$

(0.92)

$0.168 * *$

(10.45)

0.102

0.035

0.036

(1.71)

0.040

(2.26)

-0.060 *

(4.73)

$-0.084 * *$

(18.78)

466
0.0590 466
$-0.037$

(2.05)

0.056

0.031

0.035

(2.29)

(6.16)

0.036

(1.84)

$-0.068 *$

0.036

$0.102 * *$

(8.55)

0.036

0.032

0.026

0.038

$-0.068 * *$

(11.18)

$-0.043$

$-0.023$

(0.17)

$-0.065^{* *}$

(11.84)

$-0.057^{*}$

(4.56)

$-0.088^{* *}$

(18.70)

$-0.072 * *$

(7.34)

0.0673

0.0790
0.0457 466 
We also control for the number of countries in which a fund invests. As the number of foreign countries in the portfolio grows, the country-specific knowledge that an advisor may possess diminishes in value (in the context of the whole portfolio). Thus, we expect that as the number of countries in the portfolio increases, the likelihood of moving the decision rights outside the U.S. decreases. We see in Table 4 that this expectation is confirmed empirically.

\subsection{Allocating decision rights to sub-advisors}

We next consider the allocation of decision rights between advisors and sub-advisors for the sample of funds investing in domestic assets. When examining the allocation of decision rights to a sub-advisor, it seems likely that advisor characteristics will be relevant to the decision, as well as portfolio composition. For example, suppose that there are economies of scale associated with the production of information. This is likely to be the case if for no other reason than the cost of producing a given piece of information is likely to be unrelated to the amount of assets to which that information is applied. Small advisors might not have discretion over a large enough set of assets to fully realize the economies of scale in information production. We might expect, then, that small advisory firms will be more likely to allocate decision rights to a sub-advisor. We control for advisor size by including advisor assets under management in the regressions.

Also, the range (i.e., number) of different funds offered by an advisor might be relevant to the allocation of decision rights. A large number of funds might indicate a broad range of mutual fund offerings (in terms of type). As noted above, an advisor may find it desirable to offer a broad range of funds, but choose to manage only a subset of those funds. Thus, we expect that an advisor offering a large number of funds is more likely to allocate decision rights to a sub-advisor than an advisor offering only a small number of funds.

We also include dichotomous variables that capture whether a fund invests in derivatives or restricted securities during the reporting period. ${ }^{17}$ We do so because these types of assets may require specialized knowledge that is costly to produce. To the extent there are fixed costs to acquiring such knowledge, and to the extent that these securities make up a meaningful portion of fund investments, we might expect to observe funds investing in these types of assets to allocate portfolio decision rights to sub-advisors (who are, potentially, able to spread the fixed costs across a larger set of assets). We note, though, that our expectation is contingent upon these types of assets comprising a meaningful portion of fund holdings. This may not, in fact, be the case. For example, restricted securities are constrained by regulatory maximum to be no more than $15 \%$ of fund assets. As such, we may not detect any relation between investment in such securities and the allocation of portfolio decision rights to a sub-advisor.

We also include portfolio turnover in our analysis as a potential indicator of the amount of specific knowledge. Edelen (1999) documents that turnover is related to discretionary trading by portfolio managers. Thus, turnover is potentially correlated with the degree of advisor knowledge. Unfortunately, turnover is affected by other factors, such as fund investors' liquidity demands. Thus, portfolio turnover is likely to be a noisy proxy of specific knowledge, but we include it in the analysis for completeness.

Results from our examination of the allocation of decision rights to a sub-advisor are reported in Table 5. We report three alternative regression specifications: one excluding advisor characteristics, one including advisor characteristics, and one including the interaction between fund type and advisor specialization. Consistent with our third hypothesis (and the univariate analysis), we see that equity 
funds are more likely to allocate decision rights to a sub-advisor than debt funds. Evaluating the estimated relation from the third regression for a debt fund with every other variable fixed at its mean implies a probability of $3.4 \%$ that a debt fund will allocate decision rights to a sub-advisor. Calculating the same implied probability for an equity fund yields a result of $13.6 \%$, which is a $400 \%$ increase in the likelihood that an equity fund will allocate portfolio decision rights to a sub-advisor relative to a debt fund. Portfolio composition has a meaningful effect on organizational design (as captured by the use of sub-advisors).

Table 5. Logit analysis of the allocation of decision rights to a sub-advisor for funds investing in domestic assets.

Our data are from the SEC's Electronic Data Gathering and Retrieval (EDGAR) website. The source is investment company form N-SARB and advisor form ADV. We regress an indicator variable capturing whether portfolio decision rights are held by a sub-advisor on the various fund characteristics. Equity is a dichotomous variable taking a value of one if a fund invests primarily in equity securities and zero if invests primarily in debt securities. Derivatives is a dichotomous variable taking a value of one if a fund invests in derivatives and zero otherwise. Restricted Securities is a dichotomous variable taking a value of one if a fund invests in restricted securities and zero otherwise. Turnover is the lesser of purchases or sales divided by average net assets. Number of funds managed by advisor and Advisor assets under management are the number of funds and the total amount of assets, within our overall sample, managed by an advisor. Advisor equity concentration is the amount of equity fund assets managed by an advisor divided by the total amount of assets managed by the advisor.

Equity*Advisor equity concentration is the product of Equity and Advisor equity concentration. In the case of a dichotomous explanatory variable, the coefficient we report represents the incremental effect of that variable taking the value of one relative to the probability captured by the intercept. In the case of a continuous explanatory variable, the coefficient is the change in the probability implied by a two-standard-deviation increase in the variable (relative to the probability implied by evaluating the function with all dichotomous variables set to zero and all continuous variables evaluated at their means). For example, in the first regression an equity fund is $9.16 \%$ more likely to have decision rights allocated to a sub-advisor than a debt fund. (The implied probability for a fund that does not invest in restricted securities is $7.2 \%$ while for a fund that does invest in restricted securities is $7.3 \%=7.2 \%+0.1 \%$.) pseudo- $R^{2}$ is calculated as $1-[\ln L(\Omega) / \ln L(\omega)]$ where $L(\omega)$ is the likelihood function under the null hypothesis that all coefficients are 0 and $L(\Omega)$ is the likelihood function evaluated using the estimated coefficients. ${ }^{* *}$ indicates significance at the $1 \%$ level. ${ }^{*}$ indicates significance at the $5 \%$ level.

$\begin{array}{llll} & \mathbf{( 1 )} & \mathbf{( 2 )} & \mathbf{( 3 )} \\ \text { Intercept } & 0.072^{* *} & 0.054^{* *} & 0.034^{* *} \\ & (376.97) & (195.61) & (130.52) \\ \text { Equity } & 0.0916^{* *} & 0.0582^{* *} & 0.102^{* *} \\ & (46.3) & (25.74) & (21.63) \\ \text { Derivatives } & -0.0003 & 0.010 & 0.006 \\ & (0.002) & (1.87) & (1.77) \\ \text { Restricted Securities } & 0.001 & 0.009 & 0.005 \\ & (0.013) & (1.35) & (1.18) \\ \text { Turnover } & 0.0086 & 0.006 & 0.004 \\ & (2.21) & (1.58) & (1.64) \\ \text { Advisor assets under management } & & -0.052^{* *} & -0.033^{* *} \\ & & (64.63) & (66.97)\end{array}$


(1)

Advisor equity concentration

Equity*Advisor equity concentration

Number of funds managed by advisor

pseudo- $R^{2}$

Obs.

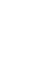
r

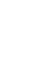

(2)

0.004 
We consider the allocation of decision rights to sub-advisors for the equity and debt fund sub-samples in Table 6. In the first two columns we consider the decision right allocation for equity funds investing for capital appreciation relative to equity funds investing for income. Our expectation is that equity funds investing for capital appreciation will be more likely to allocate decision rights to sub-advisors than equity funds investing for income. In the final two columns of Table 6 we consider the allocation of decision rights for debt funds investing in corporate debt relative to debt funds investing in government debt. We expect that debt funds investing in corporate debt will be more likely to allocate decision rights to sub-advisors than funds investing in government debt.

Table 6. Logit analysis of the allocation of decision rights to a sub-advisor within the domestic equity and debt sub-samples.

Our data are from the SEC's Electronic Data Gathering and Retrieval (EDGAR) website. The source is investment company form N-SARB and advisor form ADV. We regress an indicator variable capturing whether portfolio decision rights are by a sub-advisor on the various fund characteristics. Capital Gains is a dichotomous variable taking a value of one if a fund invests for capital gains and zero if invests for income. Corporate is a dichotomous variable taking a value of one if a debt fund invests primarily in corporate and zero otherwise. Derivatives is a dichotomous variable taking a value of one if a fund invests in derivatives and zero otherwise. Restricted Securities is a dichotomous variable taking a value of one if a fund invests in restricted securities and zero otherwise. Turnover is the lesser of purchases or sales divided by average net assets. Number of funds managed by advisor and Advisor assets under management are the number of funds and the total amount of assets, within our overall sample, managed by an advisor. Advisor capital gains concentration is the amount of capital gains fund assets managed by an advisor divided by the total amount of assets managed by the advisor. Capital Gains*Advisor capital gains concentration is the product of Capital Gains and Advisor capital gains concentration. Advisor corporate concentration is the amount of corporate fund assets managed by an advisor divided by the total amount of assets managed by the advisor. Corporate*Advisor corporate concentration is the product of Corporate and Advisor corporate concentration. In the case of a dichotomous explanatory variable, the coefficient we report represents the incremental effect of that variable taking the value of one relative to the probability captured by the intercept. In the case of a continuous explanatory variable, the coefficient is the change in the probability implied by a two-standard-deviation increase in the variable (relative to the probability implied by evaluating the function with all dichotomous variables set to zero and all continuous variables evaluated at their means). For example, in the first regression a capital gains fund is $5.6 \%$ more likely to have decision rights allocated to a sub-advisor than a debt fund. (The implied probability for a fund that does not invest in restricted securities is $10.0 \%$ while for a fund that does invest in restricted securities is $11.4 \%=10.0 \%+1.4 \%$.) pseudo- $R^{2}$ is calculated as $1-[\ln L(\Omega) / \ln L(\omega)]$ where $L(\omega)$ is the likelihood function under the null hypothesis that all coefficients are 0 and $L(\Omega)$ is the likelihood function evaluated using the estimated coefficients. ${ }^{* *}$ indicates significance at the $1 \%$ level. ${ }^{*}$ indicates significance at the $5 \%$ level.

Equity fund sub-sample Debt fund sub-sample

$\begin{array}{llll}\text { (1) (2) } & \text { (3) }\end{array}$

Intercept

$0.100 * *$

(180.55)

Capital Gains

$0.056 * *$

Corporate

Derivatives
$0.070 * *$

(195.82)

$0.152 * *$

(49.66)

$0.033 * *$

(97.26)

$0.053 * *$

(93.08)
$0.037^{* *}$

(7.59)

$0.025^{*}$

0.045

0.039* 
Equity fund sub-sample Debt fund sub-sample

Turnover

Number of funds managed by advisor

Advisor assets under management

Advisor capital gains concentration

Capital Gains*Advisor capital gains concentration

Advisor corporate concentration

Corporate*Advisor corporate concentration

pseudo- $R^{2}$

Obs.
(1)

(0.16)

0.014

(0.78)

(2)

(0.22)

0.011

0.003

(0.08)

$0.193 * *$

$-0.097^{* *}$

(60.31)

$-0.046^{* *}$

0.002

(0.10)

$0.109 * *$

(25.85)

$-0.068 * *$

(55.98)

(3)

(4.34)

(4)

$\begin{array}{ll}-0.001 & -0.002\end{array}$

(0.02)

(0.03)

$0.017^{*} \quad 0.026^{*}$

(6.43)

(6.35)

$0.004 \quad 0.008$

(0.07)

(0.10)

$-0.031 * * \quad-0.049 * *$

(8.68)

(8.72)
(22.17)

$0.038 *$

(4.67)

$-0.059 * *$

(38.35)

$-0.013$

0.051

(3.63)

0.017

(0.47)

$\begin{array}{llll}0.053 & 0.069 & 0.047 & 0.047 \\ 2,204 & 2,204 & 1,041 & 1,041\end{array}$

Consistent with our fourth hypothesis, the results reported in Table 6 suggest that equity funds investing for capital appreciation are more likely to allocate portfolio decision rights to sub-advisors than equity funds investing for income. In other words, in those instances where there is greater specific knowledge and, consequently, a greater opportunity cost associated with not matching decision rights with specific knowledge, we see outcomes consistent with decision rights being collocated with specific knowledge. Specifically, the implied probability that portfolio decision rights will be allocated to a sub-advisor rises 15.2 percentage points from $7 \%$ for equity funds investing for income to $22.2 \%$ for equity funds investing for capital gains. ${ }^{18}$

Our advisor characteristics results are consistent with the full sample. Among equity funds, small advisors and advisors managing large numbers of funds are more likely to allocate decision rights to a sub-advisor. In the second regression we see that the effect of advisor concentration in capital appreciation depends on fund type. Greater advisor concentration in managing capital appreciation funds reduces the likelihood that a capital appreciation fund will have a sub-advisor (i.e., Capital Appreciation=1), but it increases the likelihood for income funds (i.e, Capital Appreciation=0). Likewise, the marginal effect of fund type depends on advisor concentration. Consistent with our hypothesis, funds investing for capital appreciation are more likely to be sub-advised, but the likelihood of subadvising declines for an advisor that concentrates in capital appreciation investments. In slightly 
different terms, advisors are more likely to allocate decision rights for funds investing for capital appreciation unless the fund advisors, themselves, specialize in capital appreciation funds.

Finally, we see that, among debt funds, the allocation of decision rights to sub-advisors is consistent with the matching of decision rights with specific knowledge where the opportunity costs of not doing so are large. In particular, we see that funds investing in corporate debt are more likely to have portfolio decision rights allocated to a sub-advisor than funds investing in government debt. We find that the probability that a fund investing in government debt allocates decision rights to a sub-advisor is only $5.3 \%$. The comparable number for a fund investing in corporate debt is $9.8 \%-$ an $85 \%$ increase in the probability of allocating decision rights to a sub-advisor. ${ }^{19}$ The evidence presented in Section 4 suggests that there is substantial variation in sub-advising across asset types.

\section{Locating decision rights and returns}

The results discussed in 3 Sample and preliminary analysis, 4 Multivariate analysis of the location of decision rights suggest that funds allocate decision rights to collocate decision rights with specific knowledge. In this section we examine the effect of sub-advising on portfolio returns. Our earlier results suggest that the location of portfolio decision rights is driven by the tradeoff described earlier. Given these results and assuming competitive equilibrium, we expect sub-advised funds will generate risk-adjusted returns equal to those of funds that are not sub-advised.

To examine the effect of sub-advising on risk-adjusted returns, we hand match our sample of domestic equity funds to the CRSP Survivor-Bias-Free U.S. Mutual Fund Database (hereafter referred to as CRSP) for the period from January 1998 to June 2005. We limit our sample to domestic equity funds because we believe that our (Fama-French four-factor) model of expectations is best specified for those funds. ${ }^{20}$ CRSP provides monthly fund returns as well as fund expenses and turnover. We estimate each fund's factor loading using a 36-month rolling estimation window (requiring a minimum of 30 observations), and by conducting a pooled estimate over the entire sample period. Using these factor loadings, we calculate each fund's risk-adjusted returns (i.e., alphas). We then use two-stage least squares regression to estimate the relationship between performance and the decision to sub-advise the fund, where the first stage examines the probability that the fund is sub-advised (Table 6, Model 2 ), and the second stage examines fund performance. Regardless of which estimation procedure we use to calculate risk-adjusted returns, the inferences with respect to sub-advising are unchanged. Therefore, for brevity we discuss only those results using rolling estimation.

Our seventh hypothesis is that risk-adjusted returns for sub-advised funds should be indistinguishable from the risk-adjusted returns for funds that are not sub-advised. In Panel A of Table 6, we see that as the predicted probability of being sub-advised increases, funds produce lower returns. This result appears to run contrary to the notion of a competitive mutual fund industry. While this result is relatively small, on the order of $1 \%$ per year, if sub-advised funds consistently underperform their nonsub-advised counterparts, we would expect them to be competed out of the marketplace. ${ }^{21}$ We found earlier, however, that funds investing in certain types of assets are more likely to be sub-advised. For example, a growth fund is more likely to be sub-advised than an income fund. Given that finding, it is possible that the underperformance of sub-advised funds may result from the poor performance of those types of assets usually held by sub-advised funds rather than the organizational form itself. For example, between June of 2000 and 2005, the Dow Jones Wilshire Large-Cap Value Index returned $5.77 \%$ compared to $-9.42 \%$ for the Dow Jones Wilshire Large-Cap Growth Index. ${ }^{22}$ As noted earlier, growth funds are more likely to be sub-advised than income funds. 
We repeat our previous two-stage analysis, but rather than using predicted probabilities of subadvising in the second-stage performance regression, we use two variables derived from the residual of the first-stage organizational form regression. In particular, we create the variable, Positive Residual, which equals one minus the predicted probability of being sub-advised for all funds that are subadvised, and zero otherwise. Smaller values of this variable are consistent with funds that are correctly sub-advised. As this variable gets smaller, then, we would expect returns to increase (i.e., the coefficient will be negative). Our second variable, Negative Residual, takes the value of the zero minus the predicted probability of being sub-advised for those funds that are not sub-advised, and zero otherwise. This number becomes less negative when our model predicts a fund should not be subadvised, and it is not. We expect that as this variable becomes less negative, returns will increase (i.e., the coefficient with be positive). Results are shown in Panel B of Table 7.

Table 7. Performance analysis.

This table presents our analysis of the affect of sub-advising on fund performance. We use a sample of 1,624 domestic equity funds, which we are able to match to the CRSP Survivor-Bias-Free U.S. Mutual Fund Database providing a sample of 84,813 fund month observations for the period January 1998-June 2005. The dependent variable is the fund's Fama-French four-factor adjusted return, where the factor loadings are estimated either over the prior 36 months (rolling estimation), or over the entire sample (pooled estimation). Panel A presents the results from the second stage of our two-stage least squares analysis, where the first stage estimates whether the fund is sub-advised or not (Model 2 of Table 5). Panel B presents the results of our Fama and MacBeth (1973) analysis. Expense Ratio is the mutual fund's reported expense ratio at time $t$. Turnover is the minimum (of aggregated sales or aggregated purchases of securities), divided by the average 12-month total net assets of the fund, at time $t$. $\operatorname{Ln}\left(\right.$ Size $\left._{t-12}\right)$ is the natural log of the fund's total net asset 12 months prior. $\operatorname{Ln}$ (Family Size $_{t-12}$ ) is the natural log of the fund's total net asset 12 months prior. Capital Gains is a dichotomous variable taking a value of one if a fund invests for capital gains and zero if invests for income. Sub-Advised is the predicted value from the first stage regression. Positive Residual is the residual from Model 2 of Table 5 for funds, which are sub-advised, and zero if the fund is advisor run. Negative Residual is the residual from Model 2 of Table 5 for fund, which are advisor run, and is zero of sub-advised funds. ${ }^{* *}$ indicates significance at the $1 \%$ level. * indicates significance at the $5 \%$ level.

Panel A: Two stage least squares

$\begin{array}{lll}\text { Intercept } & \text { Rolling } & \text { Pooled } \\ & 0.005^{* *} & 0.006^{* *} \\ \text { Expense Ratio } & (6.37) & (8.16) \\ & -0.001^{* *} & -0.001^{* *} \\ \text { Turnover } & (-2.95) & (-4.93) \\ & -0.000^{*} & -0.000^{* *} \\ \left.\text { Ln(Size }{ }_{t-12}\right) & (-2.03) & (-3.41) \\ & -0.000^{* *} & -0.000^{* *} \\ \text { Ln(Family Size } & (-4.36) & (-6.39) \\ & 0.000 & 0.000 \\ \text { Capital Gains } & (-1.91) & (-1.21) \\ & -0.001^{*} & -0.001^{*}\end{array}$


Panel A: Two stage least squares
Sub-Advised
Rolling
Pooled
$-0.006^{* *}$
$-0.007^{* *}$
$(-2.75)$

Panel B: Performance of deviation from predicted outsourcing based on sub-advising status

\begin{tabular}{|c|c|c|}
\hline \multirow[b]{2}{*}{ Intercept } & \multicolumn{2}{|c|}{ Rolling } \\
\hline & 0.003 & $0.003 * *$ \\
\hline & (1.58) & $(2.72)$ \\
\hline \multirow[t]{2}{*}{ Expense Ratio } & -0.031 & -0.059 \\
\hline & $(-0.58)$ & $(-1.29)$ \\
\hline \multirow[t]{2}{*}{ Turnover } & 0.000 & -0.001 \\
\hline & $(-1.52)$ & $(-1.98)$ \\
\hline \multirow[t]{2}{*}{$\operatorname{Ln}\left(\right.$ Size $\left._{t-12}\right)$} & 0.00 & $-0.000 * *$ \\
\hline & $(-1.75)$ & $(-3.89)$ \\
\hline \multirow[t]{2}{*}{ Ln(Family Size $t-12)$} & 0.000 & 0.000 \\
\hline & $(-0.71)$ & $(-0.28)$ \\
\hline \multirow[t]{2}{*}{ Capital Gains } & -0.001 & -0.001 \\
\hline & $(-1.63)$ & $(-1.67)$ \\
\hline \multirow[t]{2}{*}{ Positive Residual } & $-0.001 *$ & $-0.001^{*}$ \\
\hline & $(-2.33)$ & $(-2.63)$ \\
\hline \multirow[t]{2}{*}{ Negative Residual } & $0.004 *$ & $0.004 * *$ \\
\hline & $(2.43)$ & $(3.46)$ \\
\hline
\end{tabular}

The coefficient on Positive Residual is significantly negative, indicating that as the residual becomes smaller (i.e., the decision to sub-advise is more correct), abnormal returns increase. Likewise, the significantly positive coefficient on Negative Residual indicates that as the negative residual becomes less negative (i.e., the decision not to sub-advise is more correct), returns become more positive. These results confirm our expectations and suggest that the correct organizational form is associated with improved fund performance.

Although not a primary concern of our paper, we also test the proposition that errors in organizational form are associated with differing performance by comparing the two residual term coefficients (specifically, we test the hypothesis that the sum of the two equals zero). We are able to reject the hypothesis ( $p$-value=.061) and so, given the relative magnitude of the two coefficients, we conclude that not sub-advising a fund when it should be sub-advised is associated with poorer performance than sub-advising a fund when it should not be sub-advised. Taking our results on organizational form and performance together, it is tempting to suggest that the (incorrect) choice of organizational form causes poor performance. We note, however, that while our results are consistent with this interpretation, our methodology does not allow us to directly examine causality. 


\section{Conclusion}

If value-relevant knowledge is costly to transfer and if that knowledge is unequally distributed in the economy, then the location of decision rights becomes relevant. If an advisor does not have the relevant specific knowledge then there are potential gains to shifting the decision rights to a subadvisor who does. We hypothesize that the efficient allocation of decision rights depends on a tradeoff between the opportunity cost of not matching decision rights with value-relevant specific knowledge and the agency costs associated with moving decision rights to those with specific knowledge. We argue that when the opportunity costs of not matching decision rights with specific knowledge are large, we expect to observe the allocation of decision rights towards those with the relevant knowledge. Our results are consistent with that expectation.

Specifically, we find that funds investing in foreign assets are more likely to locate portfolio decision rights outside the U.S. Also, among foreign funds we find that the likelihood of locating decision rights outside of the U.S. is greater when funds invest in countries with higher transaction costs, less openness/transparency, and weaker rule of law. We argue that this reflects the collocation of decision rights with specific knowledge, and reflects the large opportunity costs associated with not doing so.

Likewise, when we examine the use of sub-advisors among funds investing in domestic assets, we find that equity funds are more likely to allocate portfolio decision rights to a sub-advisor than are debt funds. Also, we find that, among equity funds, those funds investing for capital appreciation are more likely to allocate portfolio decision rights to a sub-advisor than are funds investing for income. Finally, we find that, among debt funds, those funds investing in corporate debt are more likely to allocate portfolio decision rights to a sub-advisor than those investing in corporate debt, unless the advisor specializes in those types of funds. We argue that all of these results are consistent with an efficient matching of decision rights and specific knowledge.

We also examine the performance of sub-advised funds. We find that how a sub-advised fund performs is a function of the underlying economics. When the economics suggest that a fund should be sub-advised, a sub-advised fund will outperform an advisor run fund. This result confirms the notion that sub-advising is a potentially useful organizational form.

Although described in greater detail in the body of the paper, the differences between our paper and that of Chen et al. (2007) bear repeating. Chen et al. blend sub-advised and team managed funds into one sample of "outsourced" funds. Because we suspect that the economics that drive the decision to split decision rights might be different from the economics that drive the decision to transfer decision rights, we focus only on sub-advised funds. We find very clear patterns in sub-advising that are linked to economic expediency, Chen et al. find no such patterns in outsourcing. Finally, our conclusions with respect to performance are diametrically opposed. Chen et al. find that outsourced funds produce inferior returns. We find that when the underlying economics predict that funds should be sub-advised and they are, those funds produce significantly higher returns than funds that are predicted to be subadvised, but that are not. Thus, the two papers are quite different in their execution and conclusions.

\section{Acknowledgments}

We have benefitted from the comments of Eugene Kandel (the Editor), Federico Nardari, Jeffrey Pontiff, Deon Strickland, an anonymous referee, participants at the 2005 Financial Management Association meetings and seminar participants at Arizona State University and DePaul University. 


\section{References}

Alchian, A.A., 1950. Uncertainty, evolution, and economic theory. Journal of Political Economy 58, 211221.

Almazan, A., Brown, K.C., Carlson, M., Chapman, D.A., 2004. Why constrain your mutual fund manager? Journal of Financial Economics 73, 289-322.

Baumol, W.J., Goldfeld, S.M., Gordon, L.A., Koehn, M.F., 1990. The Economics of Mutual Fund Markets: Competition Versus Regulation. Kluwer Academic Publishers, Boston.

Brickley, J.A., Dark, F.H., 1987. The choice of organizational form: the case of franchising. Journal of Financial Economics 18, 401-420.

Brickley, J.A., Linck, J.S., Smith Jr., C.W., 2003. Boundaries of the firm: evidence from the banking industry. Journal of Financial Economics 70, 351-383.

Chen, J., Hong, H., Kubik, J.D., 2007. Outsourcing mutual fund management: firm boundaries, incentives, and performance. Working paper, University of California Davis, Princeton University, Syracuse University.

Choe, H., Kho, B.C., Stulz, R.M., 2004. Do domestic investors have an edge? The trading experience of foreign investors in Korea. Working paper, Seoul National University, Seoul National University, Ohio State University.

Chordia, T., 1996. The structure of mutual fund charges. Journal of Financial Economics 41, 3-39.

Coles, J., Suay, J., Woodbury, D., 2000. Fund advisor compensation in closed-end funds. Journal of Finance 55, 1385-1414.

Coval, J.D., Moskowitz, T.J., 1999. Home bias at home: local equity preference in domestic portfolios. Journal of Finance 54, 2045-2073.

Coval, J.D., Moskowitz, T.J., 2001. The geography of investment: informed trading and asset prices. Journal of Political Economy 109, 811-841.

David, R.J., Han, S.K., 2004. A systematic assessment of the empirical support for transaction cost economics. Strategic Management Journal 25, 39-58.

Deli, D.N., 2002. Mutual fund advisory contracts: an empirical investigation. Journal of Finance 57, 109133.

Deli, D.N., Varma, R., 2002a. Closed-end versus open end: the choice of organizational form. Journal of Corporate Finance 8, 1-27.

Deli, D.N., Varma, R., 2002b. Contracting in the investment management industry: evidence from mutual funds. Journal of Financial Economics 63, 79-98.

Dvorak, T., 2005. Do domestic investors have an information advantage? Evidence from Indonesia. Journal of Finance 60, 817-839.

Edelen, R.M., 1999. Investors flows and the assessed performance of open-end mutual funds. Journal of Financial Economics 53, 439-466.

Fama, E.F., MacBeth, J.D., 1973. Risk, return, and equilibrium: empirical tests. Journal of Political Economy 81, 607-636.

Fama, E.F., Jensen, M.C., 1983a. Agency problems and residual claims. Journal of Law and Economics 26, 327-349.

Fama, E.F., Jensen, M.C., 1983b. Separation of ownership and control. Journal of Law and Economics 26, 301-325.

French, K.R., Poterba, J.M., 1991. Investor diversification and international equity markets. American Economic Review 81, 222-226. 
Gallaher, S., Kaniel, R., Starks, L.T., 2006. Madison avenue meets wall street: mutual fund families, competition and advertising. Working paper, University of Texas, Duke University, University of Texas.

Golec, J., Starks, L.T., 2004. Performance fee contract change and mutual fund risk. Journal of Financial Economics 73, 93-118.

Hayek, F.A., 1945. The use of knowledge in society. American Economic Review 35, 519-530.

Ivkovic, Z., Weisbenner, S., 2005. Local does as local is: information content of the geography of individual investors' common stock investments. Journal of Finance 60, 267-306.

Jensen, M.C., Meckling, W., 1976. Theory of the firm: managerial behavior, agency costs and ownership structure. Journal of Financial Economics 3, 305-360.

Jensen, M.C., 1989. The eclipse of the public corporation. Harvard Business Review, 61-74 SeptemberOctober.

Jensen, M.C., Meckling, W., 1992. Specific and general knowledge, and organizational structure. In: Werin, L., Wijkander, H. (Eds.), Contract Economics. Blackwell, Oxford, pp. 251-274.

Jin, L., Myers, S.C., 2006. R-squared around the world: new theory and new tests. Journal of Financial Economics 79, 257-292.

Joskow, P.L., 1988. Asset specificity and the structure of vertical relationships: empirical evidence. Journal of Law, Economics, and Organization 4, 95-117.

Kang, J.K., Stulz, R.M., 1997. Why is there a home bias? An analysis of foreign equity portfolio ownership in Japan. Journal of Financial Economics 46, 3-28.

Karpoff, J.M., 2001. Public versus private initiative in arctic exploration: the effects of incentives and organizational structure. Journal of Political Economy 109, 38-78.

Klein, P.G., 2004. The make-or-buy decision: lessons from empirical studies. Working paper, University of Missouri-Columbia.

Kuhnen, C.M., 2005. Inefficiencies in dynamic contracting in the mutual fund industry. Working paper, Northwestern University.

La Porta, R., Lopez-de-Silanes, F., Shleifer, A., Vishny, R.W., 1997. Legal determinants of external finance. Journal of Finance 52, 1131-1150.

La Porta, P., Lopez-de-Silanes, F., Shleifer, A., Vishny, R., 1999. The quality of government. The Journal of Law, Economics, and Organization 15, 222-279.

Lesmond, D.A., Ogden, J.P., Trzcinka, C.A., 1999. A new estimate of transaction costs. Review of Financial Studies 12, 1113-1141.

Malloy, C.J., 2005. The geography of equity analysis. Journal of Finance 60, 719-755.

Mayers, D., Smith Jr., C.W., 1986. Ownership structure and control: the mutualization of stock life insurance companies. Journal of Financial Economics 16, 73-98.

Masters, J.K., Miles, G., 2002. Predicting the use of external labor arrangements: a test of the transaction cost perspective. Academy of Management Journal 45, 431-442.

Monteverde, K., Teece, D.J., 1982a. Appropriable rents and quasi-vertical integration. Journal of Law and Economics 25, 321-328.

Monteverde, K., Teece, D.J., 1982b. Supplier switching costs and vertical integration in the automobile industry. Bell Journal of Economics 13, 206-213.

Nanda, V., Wang, Z.J., Zheng, L., 2005. The ABCs of mutual funds: a natural experiment on fund flows and performance. Working paper, Arizona State University, University of Illinois at UrbanaChampaign, University of California Irvine.

Pollack, M.E., 1990. Resales of restricted securities under SEC rules 144 and 144a, The Bureau of National Affairs, Washington, DC. 
Shelanski, H.A., Klein, P.G., 1995. Empirical research in transaction cost economics: a review and assessment. Journal of Law, Economics and Organization 11, 335-361.

Smith Jr., C.W., Wakeman, L.M., 1985. Determinants of corporate leasing policy. Journal of Finance 40, 895-908.

Tufano, P., Sevick, M., 1997. Board structure and fee-setting in the U.S. mutual fund industry. Journal of Financial Economics 46, 321-355.

Vannoni, D., 2002. Empirical studies of vertical integration: the transaction cost orthodoxy. International Review of Economics and Business 49, 113-141.

Wahal, S., Wang, A., 2008. Competition among mutual funds. Working paper, Arizona State University, Chinese University of Hong Kong.

Warner, J.B., Wu, J.S., 2004. Changes in mutual fund advisory contracts. Working paper, University of Rochester.

${ }^{1}$ Advisors may choose to offer several investment strategies. Gallaher et al. (2006) find that the more investment strategies a mutual fund family offers, the larger the flows to the family.

${ }^{2}$ Chen et al. (2007) is a notable exception discussed in greater detail later in this paper.

${ }^{3}$ For example, Fama and Jensen, 1983a, Fama and Jensen, 1983b, Smith and Wakeman (1985), Mayers and Smith (1986), Brickley and Dark (1987), Jensen (1989), Karpoff (2001), Brickley et al. (2003).

"Joskow (1988), Shelanski and Klein (1995), Vannoni (2002), David and Han (2004), Klein (2004) provide useful surveys of this literature.

${ }^{5}$ Specific knowledge has been considered by some to be a form of specific asset (c.f., Monteverde and Teece, 1982a, Monteverde and Teece, 1982b; Masters and Miles, 2002).

${ }^{6}$ In our sample, $96 \%$ of funds are managed by domestic advisors or sub-advisors and $86 \%$ are managed by an advisor (without a sub-advisor).

${ }^{7}$ We also consider the relevance of geographic location, and variation in foreign investments environments to security pricing complexity below.

8This assumption is consistent with the motivation behind a large literature on "home bias" in portfolio management. This literature focuses on the potential for information disparities between local and foreign (or local and distant) investment managers and its implications for investments and fund performance (c.f., French and Poterba, 1991; Kang and Stulz, 1997; Coval and Moskowitz, 1999, Coval and Moskowitz, 2001; Choe et al., 2004; Dvorak, 2005; Ivkovic and Weisbenner, 2005; Malloy, 2005).

${ }^{9}$ We discuss how we operationalize these concepts in Section 3, but for now we focus on their broad implications for sub-advising.

${ }^{10}$ Our assumption is made with respect to equity, on average, and debt, on average. It might reasonably be argued that certain equities are easier to value than certain debt securities (e.g., the equity of a large regulated entity versus the debt of a firm in financial distress). We address that possibility in analysis that follows by examining the allocation of decision rights within our equity fund and debt fund sub-samples.

${ }^{11}$ Corporate debt may also have more complex contractual arrangements making future cash flows more difficult to predict. 
${ }^{12}$ The SEC is authorized under Section 30(b) of the Investment Company Act of 1940 and Sections 13 and 15 (d) of the 1934 Act to solicit information required by form N-SAR. Disclosure of the information specified on form N-SAR is mandated under SEC Rule 30b1-1 (Semi-Annual Report for Registered Management Investment Companies).

${ }^{13}$ Funds answer the following six questions with respect to investments in equity and debt derivatives: (1) Did the fund write or invest in options on equities?, (2) Did the fund write or invest in options on stock indices?, (3) Did the fund write or invest in stock index futures?, (4) Did the fund write or invest in options on stock index futures?, (5) Did the fund write or invest in options on debt securities?, and (6) Did the fund write or invest in interest rate futures? If a fund answers "yes" to at least one of these six questions, then we classify it as investing in derivatives.

${ }^{14}$ Equity mutual funds must classify themselves as having one of the following six investment objectives: (1) aggressive capital appreciation, (2) capital appreciation, (3) growth, (4) growth and income, (5) income, and (6) total return. A mutual fund with an investment objective of aggressive capital appreciation is one that primarily and regularly seeks short-term appreciation through high-risk investment, with little or no concern for receipt of income. A mutual fund with an investment objective of capital appreciation is one that primarily or regularly invests for an intermediate-term return by investing in moderate to high-risk securities, with little or no concern for receipt of income. A mutual fund with an investment objective of growth is one that seeks long-term growth, with a moderate degree of risk. Receipt of income may be considered to some degree in selecting investments. A mutual fund with an investment objective of growth and income should invest primarily and regularly in low-risk investments with the objective of capital growth and income production. A mutual fund with an investment objective of income should make portfolio selection decisions based on income production. A mutual fund with an investment objective of total return should have a portfolio that includes a varying mix of equity and debt securities. We characterize funds with the primary investment objectives of aggressive capital appreciation and capital appreciation as funds investing for capital appreciation. We characterize all other equity funds as investing for income.

${ }^{15} \mathrm{We}$ implicitly assume that decision rights over the total fund assets have been allocated to the subadvisor. This may not, in fact, be the case. It is possible that an advisor would allocate decision rights over only some portion of fund assets to a sub-advisor. Thus, technically, our measure captures when an advisor allocates decision rights over some positive portion of fund assets to a sub-advisor.

${ }^{16}$ Statement of Eliot Spitzer, State of New York Attorney General, before the U.S. Senate Governmental Affairs Committee, subcommittee on Financial Management, the Budget, and International Security, January 27, 2004.

${ }^{17}$ Restricted securities are those acquired in a transaction or chain of transactions not involving a public offering, Pollack (1990).

${ }^{18}$ One reader suggested that the likelihood of allocating decision rights may be related to the extent to which a fund does not follow an indexing strategy. We address that possibility by examining the relation between Fama-French four-factor $R^{2}$ (see Section 5) and the likelihood of using a sub-advisor. The relation is statistically insignificant.

${ }^{19}$ There is a possibility that sub-advising is a fund family level decision rather than a fund level decision. To examine that possibility, we repeat all of the above analysis, but for only those funds that are 
members of fund families that have both internally managed and sub-advised funds. Our results are the same.

${ }^{20}$ We obtain the four-factor's monthly realizations from Kenneth French's website: http://mba.tuck.dartmouth.edu/pages/faculty/ken.french/data_library.html.

${ }^{21}$ The $1 \%$ per year estimate comes from multiplying the unconditional equity fund sub-advising probability times the sub-advisor coefficient times 12 .

${ }^{22}$ The returns for the Wilshire indexes came from: http://www.wilshire.com/Indexes/calculator/frame.htm. 